\title{
7. Moderate and mainstream: Leadership in the National Council of Women of Australia, 1930s-1970s
}

\author{
Judith Smart ${ }^{1}$ and Marian Quartly ${ }^{2}$
}

A major step in the development of women's activism and civic awareness in Australia was the formation of National Councils of Women in all States between 1896 and 1910, culminating in the emergence of the Federated Councils in 192425 and the National Council of Women of Australia (NCWA) in 1931. ${ }^{3}$ Linked to the International Council of Women (ICW), and through it first to the League of Nations and later the United Nations, the council movement provided, in the words of one of its early leaders, a conduit for mainstream Australian women's organisations and their members to 'accomplish good, useful, humane work in the best interests of the nation'. ${ }^{4}$ It aimed to 'bring together for discussion [and] the forming of public opinion, the workers who are doing the practical work of social education and improvement'. ${ }^{5}$ Because the council was conceived as an umbrella structure, existing women's groups of all kinds could gather under its shelter at national and international levels to discuss matters of common interest, to gather information and to learn from each other in order to promote peace and general wellbeing. This structure also ensured that leadership within the council would develop along the lines described by Amanda Sinclair as 'adaptive': 'a process of influence ... aimed at mobilising people towards changes $\ldots$ in values, attitudes, approaches, behaviours and ideologies. ${ }^{\prime}$

Though the councils included radicals among their affiliates, the feminist face they presented was self-consciously moderate with an emphasis on information, education and cooperation rather than on activism, agitation and opposition. The councils' two founding objectives dedicated constituent members to 'unity of thought, sympathy and purpose' among women 'of all classes, parties and creeds' and, importantly, to the 'the application of the Golden Rule to society, custom and law' in the interests of, as the preamble to the constitution put

\footnotetext{
RMIT University and The University of Melbourne.

Monash University.

3 The organisation was named the National Council of Women of Australia (NCWA) in 1931, but it became known generally as the Australian National Council of Women (ANCW) before it officially returned to the original NCWA nomenclature in 1970.

4 Australian Woman's Sphere, December 1901

5 'Presidential Address', in National Council of Women of Queensland (NCWQ), Annual Report 1930/1931, 7.

6 Amanda Sinclair, Chapter 1, this volume.
} 
it, 'the highest good of the family and the State'. ${ }^{7}$ But membership of the ICW also committed the Australian councils to a growing list of policies that reflected a broad liberal equal rights feminist agenda and inevitably involved them in lobbying and policy development, usually through specialist standing committees. Until the mid 1970s, the councils were the major voice of mainstream women's views in government and community forums, and the number of their affiliated organisations enabled NCWA leaders to claim they represented the views of more than a million Australian women. Through its ICW affiliation and its participation in regional conferences and seminars, NCWA was also the strongest non-governmental organisation channel via which Australian women could speak and be heard internationally. In this chapter, we examine the constraints this broad leadership role placed on national presidents from the 1930 s to the 1970s and the various means they employed to inform and lead their diverse membership on the issues of equity and justice to which affiliation with the ICW committed them.

The National Councils of Women (NCW) developed in a period when leadership styles available, even in politically radical feminist groups (such as Vida Goldstein's Women's Political Association or Bessie Rischbieth's Australian Federation of Women Voters), generally assumed a masculinist model of power and a hierarchical organisational structure. In the early years of the councils' history into the 1920s, status and class also played important roles in defining leadership qualities, the first presidents in most States being vice-regal wives, with their successors coming from the local social elite, whose wealth enabled them to travel and act as delegates to ICW conferences. From the late 1920s, professionally qualified women-doctors, lawyers, school principals, social workers, university teachers - became more prominent, and the spectrum of expertise grew wider in succeeding decades. It might be thought that such women would assume that, because of their social or expert status, where they led others would automatically follow. But because the councils were coalitions and affiliation was voluntary, status did not always mean power, and constitutional authority had to be adapted to specific circumstances.

From the inception of the ICW, achieving common cause among women meant that formal control by national councils over their members had to be limited and political engagement circumscribed. The version of this principle in a recent National Council of Women Victoria (NCWV) constitution reads:

The Council is broadly based non party political and non sectarian, bringing together a wide range of community interests. Therefore, an

7 Australian Woman's Sphere, December 1901. 
organisation willing to become affiliated with Council shall remain to all intents and purposes autonomous beyond compliance with the terms of this Constitution.

General adherence to this principle largely accounts for the longevity of the councils in Australia, and, as political scientist Carol Mueller has noted, the 'rulegenerating capacity' of such mass-based formal organisations has enabled them to deal more effectively with internal discord than radical collectivist ones. ${ }^{8}$ But, because of the restricted constitutional power NCW leaders could exercise over member societies and the looseness of the NCWA's federal structure, presidents and other office-bearers also had to focus on bringing members along with them rather than relying on rules and by-laws. The desirability of consensus in a rule-based context has encouraged flexibility and emphasised the value of networking and holding educational seminars and conferences. Policy has been developed by broadly representative standing committees, even if inevitably a great deal of the final writing work has fallen to a few individuals. Achieving consensus was, however, a slow process, and councils sometimes lagged behind their own more progressive affiliates.

The council movement was founded on the belief that the welfare of home and family was the basis of racial and national fitness, as well as of the ideal international order: a family of nations. Tasmanian president in 1901, Lady Dodds, quoted the ICW's first president, Lady Aberdeen, as saying: 'We hold fast to the belief that woman's first duty must be her home ... and that by its home life every country will stand or fall. ${ }^{\prime 9}$ In the mid 1920s, Mildred Muscio, newly elected NSW president and soon to be federal council president, elaborated on the public responsibility this entailed for women:

[T] here is no real opposition between women's interests inside the home and her interests outside the home. She must go outside the home in order to be efficient within it; and it is because of her real and important experience within the home that woman ought to go outside to take place in public affairs. ${ }^{10}$

Muscio also clearly recognised the change modern professional and scientific approaches had brought to this work - a process of rationalisation historical sociologist Kerreen Reiger has termed the 'disenchantment of the home'. ${ }^{11}$ Doctors, lawyers, teachers and university women in the NCW played a key

8 Carol Mueller, 'The Organisational Basis of Conflict in Contemporary Feminism', in Feminist Organizations: Harvest of the New Women's Movement, eds Myra Marx Ferree and Patricia Yancey Martin (Philadelphia: Temple University Press, 1995), 263-75.

9 Mercury [Hobart], 26 April 1901.

10 National Council of Women New South Wales (NCWNSW), Biennial Reports for 1926-1928, 3.

11 After Max Weber. See Kerreen Reiger, The Disenchantment of the Home: Modernizing the Australian Family 1880-1940 (Melbourne: Oxford University Press, 1985). 
role in this development. As Muscio observed, 'the woman who now faces ... domestic problems is not the woman who faced them half a century ago: she brings education, science, logic and experience of the outside world to aid her', for domestic problems 'have become national problems ... More and more our laws concern themselves with the affairs of the home', and thus, '[i] ndustry, economics, politics, laws are only our own experience written larger' ${ }^{12}$ In effect, the women's movement had conducted a successful assault on the formerly dominant masculinist preoccupations of the public sphere, though its representatives had not achieved the power necessary to direct strategies for redressing the problems they had highlighted. The gendered inequality in the distribution of power was thus assuming greater importance in council deliberations at the time the NCWA was emerging. While suffrage had already been won at the national level in 1902 and in all States by 1908, and the right to stand for federal and State legislatures was also conceded between 1902 and 1924, other issues of equality before the law such as equal and uniform marriage and divorce laws, equal guardianship rights and the right to sit on juries and the bench, were becoming more pressing in council forums. Matters of social and economic equality were also receiving greater consideration: representation on public boards and committees of inquiry, the right of married women to work, and equal pay.

The two issues to be considered in this chapter-uniform and equal national divorce laws and equal pay - put in tension the relationship between family and public life; but both also emphasised what Marilyn Lake has identified as the transition from a primary focus on protection to greater concern for equality. ${ }^{13}$ The work of NCWA leaders to bring their varied membership with them in support of change recognised the importance of taking the resulting discomforts and doubts into account. One key means of doing this was to invoke the Australian councils' international commitments to the ICW-also an important part of the leaders' own education and awareness of the transnational nature of many issues they faced.

\section{Divorce law}

As early as 1899, the ICW had asked all national councils to consider 'the nature of the laws concerned with the domestic relations which exist in all civilised countries'. ${ }^{14}$ In Australia only occasional attention was paid to marriage laws in the early years, such as when Rose Scott's radical plea for marriage as 'a

12 NCWNSW, Biennial Reports for 1926-1928, 3, 4.

13 Marilyn Lake, 'A History of Feminism in Australia', in Oxford Companion to Australian Feminism, ed. Barbara Caine (Melbourne: Oxford University Press, 1998).

14 Ibid., 17. 
partnership between equals economically' was met with the response that she had overlooked 'the element of love' that justified 'cheerfully accept[ing] burdens and dependence on that account' ${ }^{15}$ Most councils followed the familiar maternalist path and gave their primary attention to laws affecting children rather than the more confronting issues relating to marital breakdown. Nevertheless, it became increasingly apparent that many of the problems concerning the welfare of women and children were the result of desertion of husbands and fathers. In the Australian context, the problem was compounded by the fact that marriage law was controlled by the States. Even though Section 51 of the Commonwealth Constitution empowered the Federal Government to legislate on marriage and divorce from 1901, no national government took up the challenge until 1959. Six different sets of law and jurisdictions made enforcement of court orders across State borders extremely difficult and expensive for a woman, whose legal domicile followed that of her husband. Feminist reformers quickly concluded that uniform federal legislation was necessary, though opponents feared that the most liberal State laws would be imposed on all to the detriment of marriage as an institution.

Of all the possible remedies for women's inequality within marriage, uniform grounds for divorce had the greatest potential to divide the national councils. From the earliest period, the mainstream women's movement was more concerned to preserve marriage than to consider its dissolution. The stigma attached to divorce and fears that easier access would only bring hardship to women and children were widespread, and, given the difficulties of enforcing maintenance orders and the lack of other forms of economic security available to a married woman apart from her husband's income, these fears were well founded. In circumstances where separation or divorce did occur, it was thus important for the woman to be able to prove her respectability by assigning fault to her absent or erstwhile husband. In this context, if the councils were to pursue this issue, careful judgment and leadership skills were required.

While opposition to any measures that could make divorce easier were held by a number of NCW figures, such as Australia's first woman MP, Edith Cowan, ${ }^{16}$ radical feminists in both the ICW and the Australian councils stood opposed on principle to the unequal legal status of men and women within marriage, including unequal grounds for divorce. Council leaders had to steer a path between these views. One tactic was to call on the expertise of lawyers to provide information; another was to focus particularly on the protective purpose of reform proposals. As early as 1905, the Victorian council engaged the first Australian woman admitted to the bar, Flos Greig, to address members

15 Daily Telegraph, 26 June 1901.

16 Judith Allen, Rose Scott: Vision and Revision in Feminism (Melbourne: Oxford University Press, 1994), 148. 
on anomalies in the divorce law. ${ }^{17}$ By 1911, the NSW council was proposing support for uniform federal legislation, and, in 1912, an interstate meeting committed all councils to discuss it with their constituents. ${ }^{18}$ During 1913, both Victoria and Queensland suggested federal legislation be considered at the next gathering, ${ }^{19}$ but war intervened.

By the 1920s, the increasing numbers of women lawyers, at least in the eastern States, provided a pool of new experts able and willing to advise the councils on the anomalies of divorce law. They typically headed the councils' standing committees on laws and the legal position of women and thus acted as conduits with the ICW. At federal conferences, women lawyers such as New South Wales' Sybil Morrison were now speaking the modern language of equal rights rather than protection. Victoria's Joan Rosanove argued that marriage should be based on 'the idea of partnership and equality', rather than the husband's ownership of the wife. 'Whilst not dealing with the question of whether divorce is a good or bad institution ... there is a set of rules by which a man can divorce his wife, and another set for a woman. ${ }^{20}$ Uniform federal marriage and divorce law, they argued, was the most effective way of tackling this problem and, with the councils' growing commitment to gender equality, divorce reform was becoming less confronting than in previous years. The first meeting of the new federal council in 1925 passed a resolution in favour of uniformity and more extended consideration took place in $1926 .{ }^{21}$ In 1927 , the councils specifically agreed that the State councils would 'make further endeavours to obtain exact information on desirable amendments to the laws in each State with the object of embodying them in one Federal act ${ }^{\prime 22}$ The 1928 federal conference took a further step in reaffirming the necessity for federal legislation, delegates also stressed including the 'economic independence of wives' in any proposal and the States were asked to consider a model already in place - the Swedish marriage law, which stipulated an equal economic partnership between husband and wife - with a view to the principle being 'embodied in our Federal marriage law' ${ }^{23}$ Rose Scott was thus vindicated, though she had died three years earlier.

\footnotetext{
17 The Argus [Melbourne], 26 October 1905.

18 Sydney Morning Herald, 31 July 1912.

19 'Executive Minutes', 3 March 1913, and 'Council Minutes', 7 March 1913, both in National Council of Women of Queensland (NCWQ), NCWQ Papers, UQFL402, Minute Book 03, Fryer Library, University of Queensland, Brisbane [hereinafter NCWQ Papers]; Brisbane Courier, 10 March 1913.

20 'FCNCWA Conference', July 1926, in National Council of Women of Australia (NCWA) Papers, MS7583, Box 12, 'FCNCWA Minute Book 1924-28', National Library of Australia, Canberra [hereinafter NCWA Papers]; Ada Norris, Champions of the Impossible: A History of the National Council of Women of Victoria 1902-1977 (Melbourne: Hawthorn Press, 1978), 67-9; Housewife, [Victoria], 5 November 1929, 4.

21 'FCNCWA Conference', September 1925, and 'Brisbane', July 1926, NCWA Papers, Box 12.

22 'Report of FCNCWA Conference', in The Argus [Melbourne], 17 September 1927.

23 'FCNCWA Conference', July 1928, NCWA Papers, Box 12; National Council of Women of Queensland, Annual Report 1927/28, 25, 26.
} 
In the ensuing three decades, the Australian National Council of Women (ANCW) board regularly approached the Federal Government seeking a uniform law; but, partly at least to reassure those who remained concerned about 'easy divorce', this was always pursued in concert with protective domicile and maintenance issues, though these were also in accord with ICW policy. ${ }^{24}$ Despite the efforts of individual MPs approached by the Australian councils in the 1930s, little was achieved. In 1944, the Labor government's attorney-general assured the ANCA that its views concerning uniformity of divorce laws and Australian domicile would be considered, ${ }^{25}$ but, though another long battle for equal nationality rights for married women was won in Australia in 1946 and confirmed by the 1948 Nationality and Citizenship Act, ${ }^{26}$ there was no corresponding progress towards uniform marriage and divorce laws. When in May 1950 the NCWA secretary wrote to the new Liberal government requesting 'legislation granting Australia a common domicile and a uniform marriage and divorce law', she noted dryly that '[f]rom the time of the formation of the ANCW, in 1924, we have sent this resolution to the Government in office ${ }^{27}$ — without effect.

In pursuing uniform federal divorce legislation and retaining the support of State councils and their affiliates, NCWA leaders consistently assured members that their actions did not mean support for divorce as such. Their coupling of the matter with the domicile and maintenance issues points to the motivation of many women reformers and the point on which radicals and conservatives could come together: the need to relieve the problems of women whose marriages had irretrievably broken down. The board's actions in approaching the Government late in 1943-44 were stimulated by a motion moved by the first woman elected to the Senate, Labor's Dorothy Tangney. Tangney was primarily concerned with the plight of Australian wives deserted by their US servicemen husbands and was advised by long-term legal affiliate of the Victorian council Anna Brennan. Tangney recalled later that she raised 'the subject of uniform divorce laws' because 'I experienced the greatest difficulty in trying to get justice for the deserted wives due to variations between the different State laws concerning matrimonial causes' ${ }^{28}$ NCWA leaders supported this position, but Tangney remembered that many others did not:

\footnotetext{
24 International Council of Women(ICW), ICW Resolutions, http://www.ncwc.ca/pdf/ICW-CIF_Resolutions. pdf, 114-17. Indeed, the ICW resolution of 1924 enjoined national councils to study the text of laws relating to desertion in their countries and recommend modifications or amendments necessary. They also asked the League of Nations through its Codification of International Law committee to study the question of 'desertion of the family' and, later, to draw up a convention to enforce the payment of alimony, including sanctions against debtors.

25 'ANCW Board Minutes', 16 December 1943, 20 January 1944, 2 February 1944, NCWA Papers, Box 12.

26 M. Page Baldwin, 'Subject to Empire: Married Women and the British Nationality and Status of Aliens Act', Journal of British Studies 40(4) (October 2001): $522 \mathrm{ff}$.

27 'Attorney-General to Secretary ANCW', 20 May 1950, ANCW Correspondence 1936-1971, NCWA Papers, MS 5193/1, Folder 1.

28 Commonwealth Parliamentary Debates, Senate, 25 November 1959, 1834.
} 
I was very broadly criticised throughout Australia by many people who thought my main objective was to make divorce easier. I had to issue a public statement to show that that was not my intention, and that I did not think that if there were divorce laws in Australia any woman should be penalised merely because of geographical situation. ${ }^{29}$

In 1951, the ICW welcomed the enunciation of the principle of equality in marriage in the UN Declaration of Human Rights, and looked forward to a convention stipulating equality between spouses. Within the NCWA, this strengthened the voices of leaders concerned with women's rights in marriage, and the board asked all States to comment on what grounds for divorce should be included in federal legislation. ${ }^{30}$ The NCWV was singled out as representing the only State significantly 'out of step'31 — presumably a reference to the fact that, alone of the States, the Victorian Matrimonial Causes Act preserved the old inequitable provisions whereby a husband could divorce his wife for a single act of adultery, while a wife had to prove 'aggravated adultery'. At the same time, Victorian MHR Percy Joske, who had long worked for uniform federal legislation, was asked to advise the national board on drafting a bill, and the NCWA also took the issue to the Women's Jubilee Convention in Canberra, which requested a royal commission concerning marriage and divorce laws. ${ }^{32}$ In the ensuing months, Marie Breen, NCWA's international secretary and its main link to the ICW, joined Joske in radio broadcasts promoting reform..$^{33}$ In September 1952, the board was told that Joske was almost ready to put the bill before government and that the NCWA's Laws Standing Committee was providing him with further information. ${ }^{34}$

Now that change at last seemed possible, conservatives in the State councils revealed considerable hesitancy. Achieving consensus took delicate negotiation on the part of State presidents and the national president, Ruth Gibson. Council affiliates included organisations based in religious denominations, like the Catholic St Joan's Social and Political Alliance and the Anglican Mothers' Union-both totally opposed to any federal divorce legislation. The St Joan's Alliance feared 'all the grounds of divorce in all the States would be made grounds of divorce under Commonwealth Law'.$^{35}$ This proliferation argument was common in the State councils. A meeting of the Queensland council was told 'the allowable grounds for divorce in the various states totalled 23, but that Queensland had only 7 grounds', and that 'to achieve uniformity Queensland

29 Ibid.

30 'ANCW Board Minutes', 28 August 1951, NCWA Papers, MS7583, Box 12.

31 'ANCW Board Minutes', 23 October 1951, in ibid.

32 'ANCW Board Minutes', 11 September 1951 and 23 October 1951, in ibid.

33 'ANCW Board Minutes', 11 March 1952 and 13 May 1952, in ibid.

34 'ANCW Board Minutes', 23 September 1952, in ibid.

35 'Statement by St Joan's Alliance, Marriage and Divorce Bill 1947', NAA A432 1956/2207, National Archives of Australia, Canberra [hereinafter NAA]. 
might have to accept additional grounds which might make divorce easier'. The note-taker even-handedly summed up the mixed feelings: 'Most members were in favour of the principle of uniformity, no one wanted divorce in general made easier, everyone agreed that the first care should be to the happiness of home and family.' ${ }^{36}$

At the 1954 national conference, Ruth Gibson paid due respect to this unstable amalgam of views. While celebrating the fact that 'in the matter of divorce laws ... the ANCW has long since taken the lead in urging reforms', she promptly qualified this with a defence of family as 'the very foundation stone of national life'. At the same time, she stood for equality: 'Whatever our views on divorce, the fact remains that marked inequalities exist in law as between men and women and as between States, and it seems only fair and just that these should be removed.' Moreover: 'It does not automatically follow that with uniformity will come easier divorce ... the solution may probably lie in a suitable compromise between the existing State laws.' This careful statement proved effective: 'ANCW reaffirmed its belief in the desirability of ... uniform divorce laws for Australia' and asked the Federal Government 'to take early action' ${ }^{37}$

Yet again, the Federal Government procrastinated, though, in 1955, Joske achieved a national domicile for women with the passage of his Matrimonial Causes Bill. But not until 1957 was Joske's wideranging measure for uniform national marriage and divorce laws finally introduced to parliament. ${ }^{38}$ Again, NCWA commitment was tested by principled opposition within its own ranks. South Australia, previously strong in support of national legislation, ${ }^{39}$ was advised by its legal subcommittee to reject the Joske Bill because it contained no provision for judicial separation. Lawyer Roma Mitchell, State convenor of laws, was both a champion of equal rights and a practising Catholic. She argued that judicial separation on the SA legislative model allowed a dignified alternative to women unwilling to divorce; this provision would disappear if the Joske Bill passed. But the council executive, while thanking Mitchell, minuted: 'General feeling that opposition to the Bill of Mr Joske should not be stirred up, as it is most desirable there should be an Australian Act on Matrimonial Causes.' ${ }^{40}$

\footnotetext{
36 'Minutes of Special Meeting of the National Council of Women of Queensland', 4 November 1953, NCWQ Papers, Minute Book 14, Part b.

37 'ANCW Minutes of Conference, Adelaide', 1954, NCWA Papers, 2, 31.

38 The origins can be traced to 1947 when Evatt appointed Joske and two other lawyers to draft a uniform federal marriage and divorce law. See file, 'Marriage and Divorce Bill 1947', NAA A432 1956/2207, NAA; also Henry Finlay, To Have But Not to Hold: A History of Attitudes to Marriage and Divorce in Australia 1858-1975 (Sydney: The Federation Press, 2005), 304-07.

39 For example, 'Minutes of Executive', 4 November 1952, National Council of Women of South Australia (NCWSA) Papers, SRG297, State Library of South Australia, Adelaide, Series 1 [hereinafter NCWSA Papers].

40 'Minutes of Executive', 30 July 1957 and 12 September 1957 [insert], in ibid.
} 
In the event, Joske's Bill stalled, and he withdrew it when Prime Minister Robert Menzies promised a 'commensurate' government measure. Attorney-General Garfield Barwick's Matrimonial Causes Bill was in fact much more radical than Joske's. The grounds for divorce were scrupulously non-discriminatory in gender terms, to the extent of expecting a guilty wife to pay children's maintenance. ${ }^{41}$ Barwick also included a provision borrowed from the WA Act that allowed divorce after five years' separation - in effect divorce without a guilty party. Members from both sides of parliament condemned this clause, Labor's Dorothy Tangney on the grounds that 'in nine cases out of ten, in Western Australia, it is the women who suffer under this provision', 'dumped for some bright young thing' after years of childbearing and rearing and providing support for their husbands. ${ }^{42}$

One might expect to find this kind of opposition in the NCW but this is not the case. In the consistently conservative Queensland council, for example, there was no support for the request of a representative of the Association for the Defence of the Family to sign a petition to the Queen protesting the nofault clause. ${ }^{43}$ But nor was there overt rejoicing at the passage of the legislation in most States, probably reflecting council leaders' understanding that many members viewed uniform divorce legislation as an unfortunate necessity in a federated nation. Though the Victorian laws convener was 'delighted' that 'at last' an Australian law existed, national president Thelma Metcalfe, in her presidential address to the 1960 conference, merely noted the passage of the legislation without making any further comment. ${ }^{44}$ The councils now turned their attention to continuing maintenance problems, a minimum marriage age and removal of the marriage bar for women in the public service.

\section{Equal pay}

One of the subjects on the agenda at the 1899 ICW congress in London was equal pay for equal work, though no resolution was passed. The Australian councils gave consideration to equal pay almost from their beginnings in New South Wales in 1896, but, despite the clear advocacy of some of the more radical affiliates, leaders decided then and over the ensuing decade that 'the time had not arrived for its consideration', recognising the dangers of forcing the issue before most members were ready. Again the sticking point was the preservation

\footnotetext{
41 'Marriage and Divorce Bill 1947', NAA A432 1956/2207, NAA.

42 Commonwealth Parliamentary Debates, Senate, 25 November 1959, 1835.

43 'Minutes of General Meeting of NCWQ', 24 August 1960, NCWQ Papers, Minute Book 15, Part a.

44 National Council of Women of Victoria, Annual Report 1959, 18; National Council of Women of Australia, ANCW Report and Minutes of the Biennial Conference, Canberra, A.C.T., 29th October - 4th November, 1960, 15.
} 
of the family and women's role as wives and mothers - perceived by some to be threatened by the economic independence equal pay would make possible for women. ${ }^{45}$

From 1909, the Victorian council made tentative steps beyond discussion towards support for equal pay, though less as a matter of principle than as one of justice for a particular group of respectable middle-class women: teachers. ${ }^{46}$ The NCWV's leaders judged that, presented in this limited way, equal pay would seem less radical or threatening to the majority of its members. When its affiliate, the Women's Political Association, combined with Labor Party women to call a rally demanding equal pay legislation in July 1913, the NCW did not formally participate, though some of its more radical members, including the Lady Teachers' Association, the women's section of the People's Liberal Party and the Australian Women's Association, did. ${ }^{47}$ A year later, however, council representatives did attend a meeting to discuss the Government's refusal to remedy the position of women teachers and supported a resolution for equal pay for equal work as 'fair play'. ${ }^{48}$ The momentum was lost in the war years, though the NSW and Queensland councils resolved in 1915 to support equal pay for women taking men's positions, and, when in 1918 Victoria's women teachers revived their campaign, the council passed a resolution of support and asked all affiliated societies to send individual resolutions to the premier. ${ }^{49}$ In 1921, NCWV also joined a deputation urging equal pay for equal work in the public service. ${ }^{50}$

At this point, Australia's councils were ahead of the ICW, which had limited its discussion to conditions and pay of women workers and only established its standing committee on Trades and Professions and Employment at the Rome conference of 1914. Signs there that a more political approach was emerging were halted by war and the cessation of meetings and standing committee activities; ${ }^{51}$ however, in the immediate postwar years, the ICW moved in advance of the Australian councils. Following Article 427 of the Treaty of

\footnotetext{
45 'NCWNSW Executive', 12 November 1896 and 20 November 1896, NCWNSW Records, Minute Book 1895-1904; and 'NCWNSW Executive', 3 June 1909 and 1 July 1909, NCWNSW Records, Minute Book 19041913, Box MLK 03009.

46 'Report National Council of Women', Typescript by Evelyn Gough, NCWV International Secretary, for ICW Toronto Quinquennial Meeting, 1909; Norris, Champions of the Impossible, 14.

47 The Argus [Melbourne], 1 August 1913.

48 The Age, 3 July 1914.

49 'NCWQ Executive Minutes', 30 August 1915, NCWQ Papers, NCWQ Minute Book 04 1913-1915, Part b; Martha Sear, The National Council of Women of NSW: A Chronology 1896-1996 (Sydney: NCWNSW, 1996); 'Council Minutes', 24 July and 22 August 1918, National Council of Women of Victoria (NCWV) Papers in transit to State Library of Victoria, Melbourne [hereinafter NCWV Papers].

50 Norris, Champions of the Impossible, 41.

51 Catherine Jacques and Sylvie Lefebvre, 'The Working Methods of the ICW: From its Creation to the Second World War', in Women Changing the World: A History of the International Council of Women, eds Eliane Gubin and Leen van Molle (Brussels: Éditions Racine, 2005), 101-4.
} 
Versailles 'that men and women should receive equal remuneration for work of equal value', an executive meeting at The Hague in 1922 affirmed 'the principle of "equal pay for equal work" which signifies that payment be not influenced by the sex of the worker'. This resolution was strengthened at the full ICW meeting in Washington, DC, in 1925 to read 'that wages should be established on the basis of the occupation and not on the basis of $s e x^{\prime} .^{52}$ By this time the international movement, like Australian women's organisations, had come to link economic independence in marriage to the equal pay question. ${ }^{53}$ At the preceding conference in Kristiania, Norway, in 1920, the ICW resolved that a wife 'should be legally entitled to a certain just proportion of her husband's income'. ${ }^{54}$ In Australia in 1921, Justice Piddington, chairman of the royal commission into the basic wage (1919-20), suggested modification of the family basis of wage fixation to cover only a man and his wife, supplemented with a scheme of child endowment to be paid directly to mothers. NCW leaders, as well as labour movement women, wanted this proposal extended, suggesting substitution of an individual-based wage determination for the family-based one, with additional separate state-provided endowment of mothers as well as children. ${ }^{55}$ There could be no grounds in this view for awarding men higher wages than women doing the same work. Support for this principle was a significant step for the Australian NCW, since most women's organisations remained committed to the maternalist view of women's primary duty to home and family, and the responsibility of men as breadwinners. After discussing the 1922 ICW resolution at State council level for more than four years, ${ }^{56}$ delegates to the 1926 federal conference resolved both to 'approve of the principle of child endowment by a re-adjustment of the method of payment of wages' and 'to oppose the professional inequality of women, and demand for them equal opportunities and rights within the various employments', including 'equal pay for equal work, which signifies that wages should be established on the basis of the occupation and not on the basis of the sex'.$^{57}$

The councils also took the case for national endowment and an individual basis for wage fixation to the 1927 Royal Commission on Childhood Endowment. One of the commissioners was NCW federal president Mildred Muscio. As Lake and John Murphy have both noted, Muscio wrote the 1929 minority report with

\footnotetext{
52 ICW Resolutions, 176. They seem, however, not to have recognised the significance of using the terms 'payment' and 'wages' rather than the more encompassing 'remuneration' in Article 427 of the treaty.

53 Marilyn Lake, 'The Independence of Women and the Brotherhood of Man: Debates in the Labour Movement over Equal Pay and Motherhood Endowment in the 1920s', Labour History (63) (November 1992): $1-24$.

54 ICW Resolutions, 115.

55 Lake, 'The Independence of Women and the Brotherhood of Man', 1-24; also Penelope Johnson, 'Gender, Class and Work: The Council of Action for Equal Pay Campaign in Australia during World War II', Labour History (50) (May 1986): 134-7.

56 For example, 'NCWQ Council', 13 October 1922, NCWQ Papers, NCWQ Minute Book 06 1919-23, Part c.

57 'FCNCWA Conference', July 1926, in NCWA Papers, 'FCNCWA Minute Book 1924-28'.
} 
John Curtin in support of means-tested government endowment for third and subsequent children. Like the Labor Party women, she was forced into retreat on the breadwinner's wage, based on the needs of parents and two children. ${ }^{58}$ She saw this compromise as the best chance of achieving a modicum of economic justice for the most needy women. Child endowment would at least give the poorest mothers some independent maintenance, however inadequate, that was not dependent on what the father or husband deigned or was forced to hand out. The federal endowment scheme that was finally introduced early in 1941 was for second and subsequent children and was not means tested. There was no suggestion that the family basis of wages determination would be altered to underwrite it but it did enable the Menzies Government to negotiate with the Arbitration Court to defer wage increases. ${ }^{59}$

Throughout this period, the councils - held steadfast in part by ICW policydid not resile from support for equal pay and an individual rather than a family basis for wage fixation, though they did not campaign actively for this in the depression years and do not seem to have joined other women's organisations in support of Muriel Heagney's Council of Action for Equal Pay, formed in 1937. ${ }^{60}$ It is likely the leaders were aware that many affiliates had reservations about demanding equal pay when so many male breadwinners were unemployed. During World War II, however, the executive argued that all women in the fighting services should be awarded equal pay-also all women called up for national service. ${ }^{61}$ And, towards the end of the war, the NCWA board supported a call for legislation mandating a minimum female wage rate of 75 per cent of the male standard as a step towards equal pay. ${ }^{62}$

At the Commonwealth Arbitration Court's 1949-50 basic wage inquiry, which set women's basic rate at 75 per cent of a man's, the councils joined many women's organisations in intervening - though in rather tokenistic terms, it being agreed that international secretary Marie Breen should make a statement that equal pay had long been on the platform of Australian councils and the ICW. ${ }^{63}$ More serious engagement occurred in the basic wage case of 1952-53 against the employers' request for reduction of the women's rate to 60 per cent. In the intervening period, the International Labour Organisation (ILO)

\footnotetext{
58 John Murphy, A Decent Provision: Australian Welfare Policy, 1870-1949 (Farnham, UK, and Burlington, Vt: Ashgate, 2011): 138-49; Lake, 'The Independence of Women and the Brotherhood of Man', 1-24.

59 Murphy, A Decent Provision, 203-4.

60 For example, the 1933 NCWA conference supported equal pay and opportunity in the Federal Public Service. Norris, Champions of the Impossible, 64. Resolutions in 1935 affirmed the ICW position on the right of women, 'married or unmarried', to 'have the same right as a man to keep or obtain paid work' and 'to promote equal conditions of work between men and women'. 'NCWA Annual Meeting, Brisbane', August 1935, NCWA Papers, Box 11.

61 'ANCW Board Minutes', 29 June 1942, NCWA Papers, Box 12; Norris, Champions of the Impossible, 85.

62 'ANCW Board Minutes', 28 July 1945, NCWA Papers, Box 12.

63 'ANCW Board Minutes', 28 November 1949, in ibid.
} 
adopted its Equal Remuneration Convention (C100, 1951) in support of 'rates of remuneration established without discrimination based on sex'. The ICW, which had preserved close links with the ILO from the interwar years, 'vigorously' supported the international convention proposal. ${ }^{64}$ When the Australian delegation abstained from voting on ILO Convention 100, opting instead for the less binding Recommendation 90, NCWA, conscious of its responsibility as 'part of a vast international organisation such as the I.C.W. with its direct contacts with the United Nations', urged government ratification of the convention. ${ }^{65}$ Thus, when the Victorian Chamber of Manufactures requested the Arbitration Court to reduce the women's rate in 1952-53, NCWA moved decisively, joining the Australian Federation of Business and Professional Women in seeking leave to intervene. Molly Kingston, Legal Women's Association president and also NCWV convenor of laws, was briefed as counsel and NCWV partially funded the intervention. ${ }^{66}$

As president of NCWV in 1952 and 1953, Ada Norris was a key instigator of NCWA's decision to intervene, having been approached by the Women Graduates Association and the Legal Women's Association of Victoria. Norris, who deputised for the Australian council president in the case, stressed that their action should be viewed not as an end in itself but as part of 'their progress towards equal pay for equal work' ${ }^{67}$ While acknowledging that the Australian Council of Trade Unions (ACTU) 'carried the burden of the case', Norris judged the action of 'representatives of women's voluntary organisations' as influential and an 'important precedent for similar interventions' in 1969, 1972 and $1974 .{ }^{68}$ She must, then, have been particularly galled when, as Australia's delegate to the UN Status of Women Commission in March 1962, she was obliged by the Government to vote against a resolution calling on countries to ratify ILO Convention $100 .{ }^{69}$

Through the 1950s and early 1960s, the Liberal Government and the masculinist ACTU both claimed to support equal pay in general terms, but passed responsibility for doing anything about it to each other and to the Arbitration Court. ${ }^{70}$ NCWA was frustrated by the failure of the Liberal Government to take action in light of explicit support for equal pay in the party's platform. In 1961, the board wrote a letter of protest to the four Liberal Party women senators (three of whom had close NCWA connections) when they voted against a Labor

64 'ICW Conference, Athens 1951', in ICW Resolutions, 181.

65 Ruth Gibson's presidential address, in 'ANCW Minutes of Conference, Adelaide, 1954', NCWA Papers, 1.

66 National Council of Women of Victoria, Annual Report 1953, 6; Norris, Champions of the Impossible, 105.

67 National Council of Women of Victoria, Annual Report 1953, 6, 8.

68 Norris, Champions of the Impossible, 104-5.

69 Norris was Australia's delegate to CSW for an unprecedented three sessions from 1961 to 1963. On the Australian Government's position, see Tom Sheridan and Pat Stretton, 'Pragmatic Procrastination: Governments, Unions and Equal Pay,' Labour History 94 (May 2008): 144.

70 See ibid., 133-56. 
Party amendment to the Public Service Bill to provide for equal remuneration within the Commonwealth Public Service. The women senators were sharply reminded that had they voted for Senator Willesee's motion it would have been carried. The letter concluded: 'This protest is in conformity with ANCW's policy on equal pay for women. ${ }^{71}$ A reply came from Agnes Robertson, the senator from Western Australia. She made some effort to defend the political appropriateness of the women's vote - the amendment was a Labor Party 'red herring' to delay the passage of the Bill-but the crucial point was that Menzies himself had declared that the Government would not accept the amendment: 'So you can see that we had no option but to uphold the Government's decision at this particular time.' Robertson made it clear that this was not a decision she approved of: 'I would remind you that I have worked all my life for equal pay for equal work.' She had written to the government leader in the Senate 'asking for information', and she quoted in full his infuriatingly contradictory reply:

As you know, the official platform of the Liberal Party of Australia includes 'acceptance of the principle of equal remuneration for men and women for work of equal value'. The Government's attitude to this question has been stated on many occasions and was put quite clearly during the recent debates in Parliament on the Public Service Bill. That view is that it is for the Commonwealth Conciliation and Arbitration Commission and its associated tribunals in particular fields to determine the rates of remuneration for both men and women. ${ }^{72}$

Ada Norris was aware that change was a slow process and required patience and education. She believed, as she later wrote, that the Equal Pay Committee the NCWV set up after the 1953 basic wage case, together with the pamphlet it published, helped educate opinion - for '[i]n the long run the decisions of the court reflect the changes in society, and these changes have their origins in the thinking of individual people'.$^{73}$ In 1969, as NCWA president, Norris was again a key figure in putting together and presenting the council's case before the Arbitration Court for equal pay in the meat industries and the Commonwealth Public Service. In doing so, she joined with the Australian Federation of Women Voters, the Business and Professional Women's Association and the Union of Australian Women (UAW). The court's favourable decision would have variable repercussions for other women workers, flowing to some but not others, with actual numbers 'hard to estimate', as Norris reported. Her clear and concise summation, including a list of Commonwealth and Victorian awards and determinations attracting equal pay, was later used in preparation for the case presented to the Arbitration Court for the NCWA by Shirley Horne in November

71 'ANCW Board Minutes', 27 February 1961, NCWA Papers, Box 13.

72 'Agnes Robertson to ANCW', 10 March 1961, NCWA Papers, ANCW Correspondence, MS5193, Box 7.

73 Norris, Champions of the Impossible, 141-2. 
$1972,{ }^{74}$ and was influential in the court's decision, alongside the presentations by the UAW and Women's Liberation. By 1972, the council pointed out, 'it was estimated that only 18.24 per cent of the women in the work force now receive equal pay', and, calling on international precedent and example once more, Horne showed that the 1969 limited decision was 'out of phase with the principles enunciated by the United Nations and its associated organisation, the International Labour Organisation'. The NCWA case, prepared again by the Victorians, also pointed to recent legislation in New Zealand and to the fact that community attitudes to women's work, including that of married women, had changed - in part, they might have added, as a result of their own work amongst their affiliates and the wider community. ${ }^{75}$

All these arguments were used by Mr Justice Moore to justify the court's decision to support the new-for Australia-principle enunciated more than two decades earlier by the ILO of 'equal pay for work of equal value'. But the decision explicitly rejected the request of the NCWA and other women's groups to apply the male minimum wage to women workers and thus finally abandon the family basis of wage fixation. ${ }^{76}$ As Norris had commented of the 1969 decision, Australia could not ratify the 1951 ILO convention until its terms 'exist in law and practice throughout Australia', ${ }^{77}$ and the 1972 decision still left mandated equal pay incomplete. A single adult minimum wage was not conceded until 1974, when the NCWA again intervened, along with the UAW and the Women's Electoral Lobby. At last, in December of that year, Australia ratified ILO Convention $100 .^{78}$

\section{Conclusion}

Impatience with the slow processes and conventional procedures of the NCW partly accounted for the appeal to a younger generation of second-wave feminism. But young women's rejection of the councils as old-fashioned and conservative failed to recognise how much their 'adaptive leadership' had in fact achieved. The broad acceptance within the wider women's movement of the need for legal equality in marriage (and divorce) and in employment can be credited at least in part to the gentle pressure of the leaders of the national councils. And the reluctant adoption by government of 'women's issues' like uniform divorce

\footnotetext{
74 Ada Norris, 'Equal Pay Review (Victoria \& Commonwealth)', in Shirley Horne's equal pay file, NCWV Papers [hereinafter Horne File].

75 'Statement Made on behalf of the National Council of Women of Australia in the Commonwealth Conciliation and Arbitration Commission in Intervening in the Equal Pay Case, 3rd November 1972', Horne File.

76 'National Wage and Equal Pay Cases 1972 - Statement by Mr Justice Moore', Sydney, 15 December 1972, Horne File.

77 Norris, 'Equal Pay Review'.

78 Norris, Champions of the Impossible, 140-1, 145.
} 
law and equal pay came only when that gentle pressure - and other social and cultural changes - had established the issues as mainstream, reasonable and politically viable. This was the greatest achievement of the NCWA, and one that was intimately related to the understanding, support, inspiration and sense of responsibility its leaders drew from being part of an international movement.

\section{References}

Allen, Judith. Rose Scott: Vision and Revision in Feminism. Melbourne: Oxford University Press, 1994.

Australian Woman's Sphere. December 1901.

Baldwin, M. Page. 'Subject to Empire: Married Women and the British Nationality and Status of Aliens Act.' Journal of British Studies 40(4) (October 2001): 522-56.

Brisbane Courier, 10 March 1913.

Commonwealth Parliamentary Debates. Senate. 25 November 1959.

Daily Telegraph. 26 June 1901.

Finlay, Henry. To Have But Not to Hold: A History of Attitudes to Marriage and Divorce in Australia 1858-1975. Sydney: The Federation Press, 2005.

Housewife [Victoria]. 5 November 1929.

International Council of Women (ICW). ICW Resolutions. http://www.ncwc.ca/ pdf/ICW-CIF_Resolutions.pdf.

Jacques, Catherine and Sylvie Lefebvre. 'The Working Methods of the ICW: From its Creation to the Second World War.' In Women Changing the World: A History of the International Council of Women, edited by Eliane Gubin and Leen van Molle, 101-4. Brussels: Éditions Racine, 2005.

Johnson, Penelope. 'Gender, Class and Work: The Council of Action for Equal Pay Campaign in Australia during World War II.' Labour History 50 (May 1986): 134-7.

Lake, Marilyn. 'The Independence of Women and the Brotherhood of Man: Debates in the Labour Movement over Equal Pay and Motherhood Endowment in the 1920s.' Labour History 63 (November 1992): 1-24. 
Diversity in Leadership: Australian women, past and present

Lake, Marilyn. 'A History of Feminism in Australia.' In Oxford Companion to Australian Feminism, edited by Barbara Caine, 132-42. Melbourne: Oxford University Press, 1998.

'Marriage and Divorce Bill 1947.' NAA A432 1956/2207. National Archives of Australia, Canberra.

Mercury [Hobart]. 26 April 1901.

Mueller, Carol. 'The Organisational Basis of Conflict in Contemporary Feminism.' In Feminist Organizations: Harvest of the New Women's Movement, edited by Myra Marx Ferree and Patricia Yancey Martin, 263-75. Philadelphia: Temple University Press, 1995.

Murphy, John. A Decent Provision: Australian Welfare Policy, 1870-1949. Farnham, UK, and Burlington, Vt: Ashgate, 2011.

National Council of Women of Australia. ANCW Report and Minutes of the Biennial Conference, Canberra, A.C.T., 29th October - 4th November, 1960.

National Council of Women of Australia (NCWA) Papers. MS7583 and MS5193. National Library of Australia, Canberra.

National Council of Women of New South Wales (NCWNSW) Records. MS3739. Mitchell Library, Sydney.

National Council of Women of New South Wales. Biennial Reports for 1926-1928.

National Council of Women of Queensland (NCWQ). Papers. UQFL402. Fryer Library, University of Queensland, Brisbane.

National Council of Women of Queensland. Annual Report 1927/28; 1930/1931.

National Council of Women of South Australia (NCWSA) Papers. SRG297. State Library of South Australia, Adelaide.

National Council of Women of Victoria (NCWV). Papers in transit to State Library of Victoria, Melbourne.

National Council of Women of Victoria. Annual Report 1953.

National Council of Women of Victoria. Annual Report 1959.

Norris, Ada. Champions of the Impossible: A History of the National Council of Women of Victoria 1902-1977. Melbourne: Hawthorn Press, 1978.Reiger, Kerreen. The Disenchantment of the Home: Modernizing the Australian Family 1880-1940. Melbourne: Oxford University Press, 1985. 
'Report National Council of Women.' Typescript by Evelyn Gough, NCWV International Secretary, for ICW Toronto Quinquennial Meeting, 1909.

Sear, Martha. The National Council of Women of NSW: A Chronology 1896-1996. Sydney: NCWNSW, 1996.

Sheridan, Tom and Pat Stretton. 'Pragmatic Procrastination: Governments, Unions and Equal Pay.' Labour History 94 (May 2008): 133-56.

'Statement by St Joan's Alliance, Marriage and Divorce Bill 1947.' NAA A432 1956/2207. National Archives of Australia, Canberra.

Sydney Morning Herald. 31 July 1912.

The Age. 3 July 1914.

The Argus [Melbourne]. 26 October 1905; 1 August 1913; 17 September 1927. 
This text taken from Diversity in Leadership: Australian women, past and present, edited by Joy Damousi, Kim Rubenstein and Mary Tomsic, published 2014 by ANU Press, The Australian National University, Canberra, Australia. 